\title{
Consistency of Polyphenol Oxidase (PPO) Thermostability in Ripening Apricots (Prunus armeniaca L.): Evidence for the Presence of Thermostable PPO Forming and Destabilizing Mechanisms in Apricots
}

\author{
Ahmet YemenicioǦLU* ${ }^{*} \dagger$ AND BeKIR CEMERoĞLU ${ }^{\S}$ \\ Department of Food Engineering, Faculty of Agriculture, Ankara University, \\ 06110 Dışkap1, Ankara, Turkey, and Department of Food Engineering, Faculty of Engineering, \\ Izmir Institute of Technology, 35437 Gülbahçe Köyü, Urla, İzmir, Turkey
}

\begin{abstract}
Destabilization of thermostable polyphenol oxidase (TS-PPO) during the ripening of peaches has been previously shown (Yemenicioğlu, A.; Cemeroğlu, B. Tr. J. Agric. For. 1998, 22, 261-265). This work studied the effect of ripening on thermal stability of apricot PPO for three different cultivars. Kabaaşı cultivar contained thermolabile PPO, whereas TS-PPO appeared in Hacıhaliloğlu and Çataloğlu cultivars. The TS-PPO showed biphasic inactivation curves, and its $D$ and $z$ values between 60 and $90^{\circ} \mathrm{C}$ varied in the ranges of $357-1.12 \mathrm{~min}$ and $11.9-12.7^{\circ} \mathrm{C}$, respectively. In Hacıhaliloglu cultivar the TS-PPO was very consistent and existed at all stages of ripening, whereas in Çataloğlu cultivar it appeared only at the half-ripe stage. The loss of consistent TS-PPO in Hacıhaliloglu apricots after partial purification by acetone precipitation and DEAE-cellulose chromatography suggested the non-covalent nature of its stabilization. The main purified fractions (F1 and F2) showed monophasic inactivation curves with similar thermal inactivation parameters $\left(z_{\mathrm{F} 1}=10.4^{\circ} \mathrm{C}, z_{\mathrm{F} 2}=10.1^{\circ} \mathrm{C}\right)$. However, their kinetic properties against catechol $\left(K_{\mathrm{mF} 1}=61 \mathrm{mM}, K_{\mathrm{mF} 2}=122.7 \mathrm{mM}\right)$ and substrate specificities were considerably different. The results of this study showed the presence of TS-PPO forming and destabilizing mechanisms in apricots. Further studies are needed for the solution of these mechanisms and to develop some new strategies that may be utilized by molecular techniques for a planned production of apricot cultivars provided with heat labile but normal PPO activity.
\end{abstract}

KEYWORDS: Prunus armeniaca; apricot; ripening; polyphenol oxidase; heat inactivation; purification

\section{INTRODUCTION}

One of the biggest problems faced during the processing of fruits and vegetables is enzymatic browning, which is catalyzed by polyphenol oxidases (PPO). The use of sulfites is one of the most effective methods to prevent enzymatic browning reactions. However, due to the health concerns, there have been great efforts to minimize or eliminate the use of sulfites in food technology; this encouraged the use of sulfite alternatives, such as ascorbic acid and its derivatives, $\beta$-cyclodextrin, L-cysteine, and 4-hexylresorcinol $(1-3)$. These chemicals are less effective compared with sulfites and need some complementary treatments such as packaging under nitrogen atmosphere and/or use in combination with heat treatments, acidic solutions, or polyphosphates $(3-7)$.

A novel and promising approach for the control of PPO activity in fruits and vegetables without the use of chemicals is the use of molecular biology. By employing an antisense RNA

* Author to whom correspondence should be addressed [telephone 90 (232) 4986292; fax 90 (232) 4986355; e-mail ahmetyemenicioglu@iyte.edu.tr].

†zmir Institute of Technology.

$\S$ Ankara University. technique Bachem et al. (8) blocked PPO gene expression in potatoes and obtained very low PPO activity-containing cultivars. Coetzer et al. (9) also reduced the PPO activity in potatoes by using sense or antisense RNA techniques and successfully controlled their enzymatic browning. One of the concerns related to these methods is that PPO in plants is involved in disease and pest resistance (10). The inactivation of PPO enzymes in plants may cause a susceptibility increase to diseases and may encourage wider pesticide use. In fact, hypersusceptibility to pathogens was reported in tomatoes with reduced PPO activity induced by the use of an antisense technique (11). Thus, alternative strategies should be developed to increase the application potential of molecular techniques.

In addition to chemical and genetic methods, heat treatment is also used effectively to prevent undesirable enzymatic browning reactions during the processing of fruits and vegetables. Especially in the production of frozen or thermally processed fruit pulps, heating is a widely used method employed for the prevention of enzymatic browning. Also, because most of the emerging technologies are not very effective or cause some undesirable effects on food quality, many different studies 
have been conducted to combine moderate or mild heat treatments with high-pressure sterilization, irradiation, microwave heating, ultrasound, osmotic rehydration, or hurdle technologies $(11-17)$.

In fact, PPO enzymes do not belong to an "extremely heatstable enzyme" group, and short exposures of product to temperatures between 70 and $90{ }^{\circ} \mathrm{C}$ are sufficient to inactivate the enzymes. However, in some Prunus fruits such as cherries, plums, and apricots PPO may have a considerable thermostability (18). In particular, the thermostability of apricot PPO has been known for a very long time $(18-21)$. The thermostability of PPO enzymes may be affected by the cultivar, the physiological state, or the environmental conditions (18). Thus, it is very difficult to determine the factors causing the formation of thermostable PPO (TS-PPO). However, it is well-known that the PPO in unripe fruits is generally more heat stable than the $\mathrm{PPO}$ in ripe fruits $(18,22)$. This indicates the presence of some in situ mechanisms that reduce the consistency of TS-PPO enzyme during ripening. The primary objective of this study was to obtain some data about the consistency of PPO thermostability in different apricot cultivars during ripening and to characterize the TS-PPO enzyme form. Information about the possible mechanisms that cause the decrease or elimination of TS-PPO may help to develop a new strategy for researchers working in the field of molecular biology. The development of crops containing thermolabile, but normal, PPO activity may allow disease and pest resistance to be maintained, required exposure times to heat during processing to be shortened, and use of chemical additives to be minimized.

\section{MATERIALS AND METHODS}

Materials. The apricot cultivars used in the research were obtained form Malatya Fruit Research Institute, Turkey. The fruits were washed, drained, and classified according to their color. The green mature fruits with very little or no straw-yellow areas were designated unripe; strawyellow fruits with very little green areas and light orange fruits with straw-yellow and green areas were designated half-ripe; and orange fruits were designated ripe. The average weight of samples was determined by weighing 30 randomly selected apricots. The $\mathrm{pH}$, ${ }^{\circ}$ Brix, and titrable acidity were determined according to the standard methods given in Cemeroğlu (23) by using the homogenates obtained from 10 fruits. The average value of three measurements was used for the determination of titrable acidity, whereas other measurements were done twice. The reagents catechol, (+)-catechin, 4-methylcatechol, and DEAE-cellulose (fast flow) were obtained from Sigma Chemical Co. (St. Louis, MO). Polyamide was obtained from Roth Chemical Co. (Karlsruhe, Germany), and pyrogallol and $p$-cresol were obtained from Merck (Darmstadt, Germany).

Extraction of Enzymes. Acetone powder, obtained according to the method described by Yemenicioğlu et al. (24), was used as enzyme source in this study. The crude enzyme extracts were obtained by mixing $2-5 \mathrm{~g}$ of acetone powder, $300-350 \mathrm{~mL}$ of cold $0.01 \mathrm{M}$ sodium phosphate buffer at $\mathrm{pH} 6.5$, and $0.5 \mathrm{~g}$ of polyamide for $2 \mathrm{~h}$ at $4{ }^{\circ} \mathrm{C}$. This suspension was filtered through four layers of cheesecloth, centrifuged at $4{ }^{\circ} \mathrm{C}$ and $7000 \mathrm{~g}$ for $30 \mathrm{~min}$, and then used immediately in the heat inactivation experiments. In partial purification studies the extraction was carried out in the same above-mentioned phosphate buffer, but at $\mathrm{pH} 6.8$, with the addition of $10 \mathrm{~mL}$ of $0.05 \mathrm{M} \mathrm{CaCl}_{2}$ to induce the precipitation of pectic compounds.

Enzyme Precipitation. The acetone precipitation method, previously used in the purification of apricot PPO by Dijkstra and Walker (25), was performed in this study. For this purpose, the crude extract was mixed with 2 volumes of cold acetone at $-35^{\circ} \mathrm{C}$ and stirred slowly for $10 \mathrm{~min}$ at $4{ }^{\circ} \mathrm{C}$. The colorless precipitate was collected by filtration through a tightly woven nylon cloth, dissolved in a minimum amount of extraction buffer, and dialyzed against the same buffer $(3 \times 1500$ $\mathrm{mL})$ for $48 \mathrm{~h}$ at $4{ }^{\circ} \mathrm{C}$.
Ion Exchange Chromatography. For ion exchange chromatography we used two different DEAE-cellulose columns $(5 \times 2.5 \mathrm{~cm})$ containing 10 or $20 \mathrm{~g}$ of DEAE-cellulose matrix. Before use, these loosely and tightly filled columns were washed and equilibrated with $0.01 \mathrm{M}$ phosphate buffer. After the enzyme extracts had been loaded, the columns were eluted at $4{ }^{\circ} \mathrm{C}$ with a linear discontinuous gradient of $\mathrm{pH} 6.8$ sodium phosphate buffers $(0.01-0.34 \mathrm{M})$. The fractions $(5 \mathrm{~mL})$ collected during elution were assayed for their PPO activity, and their absorbance at $280 \mathrm{~nm}$ was determined to monitor the protein peaks.

Heat Inactivation Experiments. Heat inactivation studies were carried out according to the method of Yemenicioğlu et al. (24) within the temperature range of $60-90{ }^{\circ} \mathrm{C}$ by using thermal inactivation time (TIT) tubes (i.d., $9 \mathrm{~mm}$; wall thickness, $1 \mathrm{~mm}$ ). The $\mathrm{pH}$ values of the buffers used in these studies were 6.5 and 6.8 for the crude and partially purified enzyme extracts, respectively. To minimize the lag phase, TIT tubes containing $4 \mathrm{~mL}$ of sodium phosphate buffer were heated to inactivation temperature. Once the temperature of the buffer solution stabilized, $0.4 \mathrm{~mL}$ of enzyme extract was pipetted into TIT tubes, mixed with a vortex and immersed again into water bath. After heating for a given period, the tubes were cooled in an ice water bath and immediately assayed for PPO activity. Because of the limited amount of enzyme extract, the heat inactivation experiments of partially purified enzymes were conducted by pipetting $0.2 \mathrm{~mL}$ of enzyme extracts to preheated TIT tubes containing $2 \mathrm{~mL}$ of phosphate buffer.

Kinetic Properties. The effect of temperature on PPO activity was determined by measuring the enzyme activity at 20-60 and 20-45 ${ }^{\circ} \mathrm{C}$ for the crude and partially purified enzyme extracts, respectively. During measurements, to reduce the heating lag the enzyme extract was added to a preheated buffer and substrate mixture. Optimum $\mathrm{pH}$ was determined by using $0.1 \mathrm{M}$ sodium phosphate buffer at different $\mathrm{pH}$ values $(5.5-8)$ in reaction mixtures. Michaelis constants and maximum velocities of the enzyme fractions were determined by using the double-reciprocal plot. The final concentrations of catechol (3.2$143.2 \mathrm{mM}$ ) in cuvettes were kept around the $K_{\mathrm{m}}$ values of PPO reported in the detailed review of Vamos-Vigyazo (18). In the substrate specificity tests, the concentration of pyrogallol, catechol, 4-methylcatechol, hydroquinone, and $p$-cresol was $50 \mathrm{mM}$ and the concentration of $(+)$-catechin was $2.5 \mathrm{mM}$.

PPO Activity Determination. The activity measurements were conducted at $420 \mathrm{~nm}$ by using a Pye Unicam SPG-550 UV-vis spectrophotometer equipped with a constant-temperature cell holder. After heat inactivation experiments, for the determination of their residual catecholase or cresolase activities the TIT tubes were incubated at 30 or $35{ }^{\circ} \mathrm{C}$ for $5 \mathrm{~min}$, respectively. The catecholase activity was determined at $30^{\circ} \mathrm{C}$ by mixing $2 \mathrm{~mL}$ of TIT tube content with $0.5 \mathrm{~mL}$ of $0.5 \mathrm{M}$ catechol (at $30^{\circ} \mathrm{C}$ ) in a quartz cuvette (optical path length, 1 $\mathrm{cm}$ ), whereas cresolase activity was determined at $35^{\circ} \mathrm{C}$ by mixing 4 $\mathrm{mL}$ of tube content with $1 \mathrm{~mL}$ of $5 \mathrm{mM} p$-cresol in a glass cuvette (optical path length, $5 \mathrm{~cm}$ ). For activity measurements during partial purification and kinetic studies, $0.2-0.3 \mathrm{~mL}$ of enzyme extract was mixed with $2 \mathrm{~mL}$ of $0.01 \mathrm{M}, \mathrm{pH} 6.8$, sodium phosphate buffer in a test tube. After $5 \mathrm{~min}$ of incubation at $30^{\circ} \mathrm{C}, 2 \mathrm{~mL}$ of tube content was transferred to a quartz cuvette and $0.2-0.3 \mathrm{~mL}$ of $0.5 \mathrm{M}$ catechol at $30{ }^{\circ} \mathrm{C}$ was added to the cuvette to start the reaction. The absorbance values observed during the determination of catecholase and cresolase activity were recorded at every 10 (or 15) and $120 \mathrm{~s}$, respectively. The catecholase activity was determined from the slope of the initial linear portion of absorbance versus time curves, whereas cresolase activity was determined from the slope of the linear portion of absorbance versus time curves coming after the initial lag period. The enzyme activities were given as unit (the amount of enzyme that caused 0.001 change in absorbance in $1 \mathrm{~min}$ ) or $\Delta$ abs $\mathrm{min}^{-1} \mathrm{~mL}^{-1}$. In this study the catecholase activity was designated PPO activity unless otherwise indicated.

Protein Content. Protein was determined according to the Lowry method by using bovine serum albumin as standard (26).

\section{RESULTS AND DISCUSSION}

Consistency of PPO Thermostability during Fruit Ripening. The effect of ripening on the thermal stability of apricot PPO was investigated between 60 and $90{ }^{\circ} \mathrm{C}$ by using $0.01 \mathrm{M}$, 
Table 1. Some Characteristics of the Apricot Cultivars Used in This Study

\begin{tabular}{|c|c|c|c|c|c|}
\hline cultivar & $\begin{array}{l}\text { av wt } \\
\text { (g) }\end{array}$ & $\mathrm{pH}$ & $\begin{array}{l}\text { titrable acidity }{ }^{a} \\
\quad\left(\mathrm{~g} \mathrm{~kg}^{-1}\right)\end{array}$ & ${ }^{\circ}$ Brix & ratio $^{b}$ \\
\hline Hacıhaliloğlu & 30.3 & & & & \\
\hline unripe & & 4.92 & 17.0 & 15.8 & 0.93 \\
\hline half-ripe & & 4.98 & 17.4 & 19.6 & 1.13 \\
\hline ripe & & 4.96 & 15.4 & 20.6 & 1.34 \\
\hline Çataloğlu & 21.4 & & & & \\
\hline unripe & & 4.86 & 14.1 & 14.8 & 1.05 \\
\hline half-ripe & & 4.95 & 13.4 & 15.8 & 1.18 \\
\hline ripe & & 5.02 & 12.4 & 16.2 & 1.31 \\
\hline Kabaaşı & 31.5 & & & & \\
\hline unripe & & 4.75 & 15.4 & 11.6 & 0.75 \\
\hline half-ripe & & 4.97 & 13.0 & 14.4 & 1.11 \\
\hline ripe & & 4.94 & 13.0 & 17.2 & 1.32 \\
\hline
\end{tabular}

${ }^{a}$ Titrable acidity is given as malic acid equivalent. ${ }^{b}{ }^{\circ}$ Brix/titrable acidity.

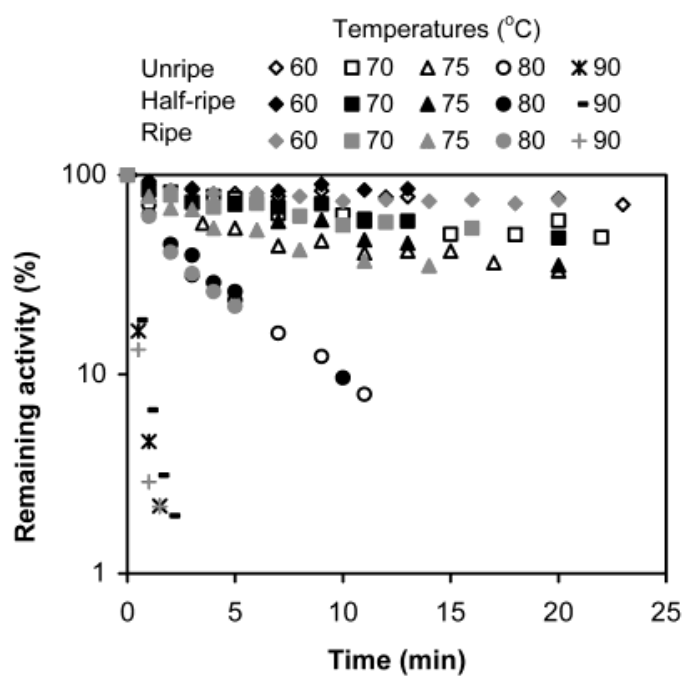

Figure 1. Heat inactivation of PPO from Hacıhalioğlu apricots at different ripening stages.

$\mathrm{pH}$ 6.5, sodium phosphate buffer as inactivation medium for the three different cultivars. Some characteristics of the apricot cultivars used in this study are given in Table 1. In all of the apricot cultivars the inactivation of PPO followed a first-order reaction kinetic. However, the courses of inactivation curves varied considerably. For example, in Hacihaliloğlu cultivar at all stages of ripening the inactivation curves were biphasic (Figure 1) and the PPO enzyme was considerably thermostable (TS) (Table 2). In contrast, in Kabaaşı apricots at all stages of ripening the enzyme was very thermolabile (TL) and its heat inactivation curves were monophasic or showed tailing at high temperatures when PPO activity reduced to below 10\% (Figure 2). PPO from Çataloğlu apricots, on the other hand, showed both monophasic (with or without tailing at high temperatures) and biphasic inactivation curves (Figure 3). In these apricots the enzyme was quite heat labile at unripe and ripe stages and showed inactivation curves similar to those of PPO in Kabaaş1 cultivar. In contrast, in half-ripe Çataloğlu apricots the course of inactivation curves was biphasic and the enzyme was very thermostable. It is worth noting that the $D$ and $z$ values of PPO in half-ripe Çataloğlu apricots are almost in the range of $D$ and $z$ values of PPO in Hacihaliloğlu apricots. Thus, these results clearly indicate the presence of consistent and inconsistent TSPPO in Hacıhaliloğlu and Çataloğlu apricots, respectively.

The biphasic inactivation curves of PPO in Hacıhaliloğlu apricots and in half-ripe Çataloğlu apricots enabled us to calculate the percentages of their TS and TL enzyme fractions. This was done as described by Yamamoto et al. (27) by extending the heat stable portion of a heat inactivation curve and finding its intercept on the $y$-axis. As shown in Table 3 between 60 and $80{ }^{\circ} \mathrm{C}$ the percentage of TS-PPO in unripe, half-ripe, and ripe Hacihaliloğlu apricots varied between 54 and 87 , between 67 and 91, and between 61 and 83, respectively. At $90{ }^{\circ} \mathrm{C}$ the percentages of TS-PPO enzyme fraction in unripe and half-ripe Hacıhaliloğlu apricots increased slightly from 42 to 44 and then dropped to 27 in ripe fruits. Because of the rapid loss of the TL enzyme's activity at $90{ }^{\circ} \mathrm{C}$, the reduction in the percentage of the TS enzyme fraction in ripe fruits was more apparent. Also, in unripe and ripe Hacıhaliloğlu apricots the TS/TL ratio dropped below 3 above $70{ }^{\circ} \mathrm{C}$. However, in halfripe Hacıhaliloğlu apricots and half-ripe Çataloğlu apricots this occurred above $75^{\circ} \mathrm{C}$. These comparisons clearly showed the increase and then reduction of the TS/TL ratio in Hacıhaliloğlu apricots at half-ripe and ripe stages, respectively. However, unlike the TS-PPO in Çataloğlu apricots a considerable portion of TS enzyme form was consistent in Hacihaliloğlu apricots and existed at all stages of ripening. Previously in our laboratory we showed the presence of inconsistent TS-PPO in Hale Haven peaches (22). In that study, by using the heat inactivation curves at $70{ }^{\circ} \mathrm{C}$, we calculated the percentages of TS-PPO in unripe, half-ripe, and ripe peaches as 87, 48, and 55, respectively. Similar to the results obtained for Hacihaliloğlu apricots, no considerable change was determined among the $D_{70^{\circ} \mathrm{C}}$ values of TS enzyme fraction in unripe, half-ripe, and ripe peaches. The disappearance of TS-PPO affected only the TS/TL ratio. Thus, these results confirm the presence of in situ TS-PPO destabilizing mechanisms in apricots and peaches.

In this study the effect of temperature on the activity of PPO from ripe apricots was also investigated. As seen in Figure 4 PPO in Kabaaşı, Çataloğlu, and Hacıhaliloğlu apricots showed optimal activity at 35,40 , and $45^{\circ} \mathrm{C}$, respectively. The higher temperature optimum of TS-PPO in Hacıhaliloğlu apricots is not surprising. However, it is quite interesting to observe that TS-PPO in these apricots and TL-PPO in Çataloğlu and Kabaaş1 apricots showed almost no activity at $65^{\circ} \mathrm{C}$. The heat inactivation studies showed that apricot PPO was quite heat stable at this temperature. Thus, the inability of enzymes to display their activity at $65{ }^{\circ} \mathrm{C}$ should be related to reversible modifications in PPOs' conformation that occurred before or after their interaction with the substrate so as to decrease or eliminate their activities. This result is in accordance with the general consideration that during processing, to control browning caused by PPO, the products should be heated very rapidly above $65^{\circ} \mathrm{C}$ (18).

To obtain more data about the similarities and differences between the TS-PPO in Hacıhaliloğlu apricots and TL-PPO in Çataloğlu and Kabaaşı apricots, we also investigated the heat stability of their cresolase activities in ripe fruits. The inactivation of PPO cresolase activity in apricots between 65 and 80 ${ }^{\circ} \mathrm{C}$ also followed a first-order reaction kinetic. However, at high temperatures a lag phase had been observed in the inactivation curves before the monophasic inactivation started. In Çataloğlu apricots the lag phases were more apparent, and at $70{ }^{\circ} \mathrm{C}$ we also initially observed a considerable increase in enzyme activity. However, when we repeated the heat inactivation study at $70{ }^{\circ} \mathrm{C}$, a lag phase was observed instead of an increase in enzyme activity (Figure 5). Thus, it is likely that the lag phase observed in heat inactivation curves was due to the activation of enzyme by heat. Comparison of the $D$ values, calculated from the linear portions of inactivation curves coming after the lag 
Table 2. Effect of Ripening on Thermostability of PPO from Different Apricot Cultivars

\begin{tabular}{|c|c|c|c|c|}
\hline \multirow[b]{2}{*}{ cultivar } & \multirow[b]{2}{*}{ temp $\left({ }^{\circ} \mathrm{C}\right)$} & \multicolumn{3}{|c|}{$D$ value (min) } \\
\hline & & unripe & half-ripe & ripe \\
\hline Hacıhaliloğlu & $\begin{array}{l}60 \\
70 \\
75 \\
80 \\
90\end{array}$ & $\begin{array}{l}278.0(20.0)^{a} \\
92.0(12.5) \\
78.0(10.0) \\
13.5(5.96) \\
1.13(0.64) \\
z=12.5^{\circ} \mathrm{C}(0.918)^{b} \\
z^{c}=20.8^{\circ} \mathrm{C}(0.845)\end{array}$ & $\begin{array}{l}286.0(33.3) \\
82.0(14.3) \\
51.0(16.7) \\
11.8(5.7) \\
1.28(0.68) \\
z=12.7^{\circ} \mathrm{C}(0.960) \\
z=18.3^{\circ} \mathrm{C}(0.870)\end{array}$ & $\begin{array}{l}357.0(25.0) \\
81.0(20.0) \\
39.0(9.1) \\
11.1(5.1) \\
1.27(0.57) \\
z=12.2^{\circ} \mathrm{C}(0.985) \\
z=18.1^{\circ} \mathrm{C}(0.881)\end{array}$ \\
\hline Kabaaşı & $\begin{array}{l}60 \\
70 \\
75 \\
80 \\
90\end{array}$ & $\begin{array}{l}313.0 \\
37.6 \\
11.6 \\
3.93 \\
0.37 \\
z=10.2^{\circ} \mathrm{C}(0.999)\end{array}$ & $\begin{array}{l}385.0 \\
47.8 \\
8.3 \\
2.1 \\
0.45 \\
z=9.9^{\circ} \mathrm{C}(0.982)\end{array}$ & $\begin{array}{l}345.0 \\
35.8 \\
11.6 \\
2.86 \\
0.39 \\
z=10.1^{\circ} \mathrm{C}(0.998)\end{array}$ \\
\hline Çataloğlu & $\begin{array}{l}60 \\
70 \\
75 \\
80 \\
90\end{array}$ & $\begin{array}{l}233.0 \\
21.9 \\
9.2 \\
2.7 \\
0.43 \\
z=11.0^{\circ} \mathrm{C}(0.997)\end{array}$ & $\begin{array}{l}345.0(33.3) \\
112.0(20.0) \\
54.0(14.3) \\
13.3(9.1) \\
1.12(0.99) \\
z=11.9^{\circ} \mathrm{C}(0.958) \\
z=20.4^{\circ} \mathrm{C}(0.865)\end{array}$ & $\begin{array}{l}124.0 \\
17.2 \\
7.5 \\
2.0 \\
0.37 \\
z=11.8^{\circ} \mathrm{C}(0.997)\end{array}$ \\
\hline
\end{tabular}

${ }^{a} D$ values of thermolabile PPO. ${ }^{b}$ Correlation coefficients. ${ }^{c} z$ values of thermolabile PPO.

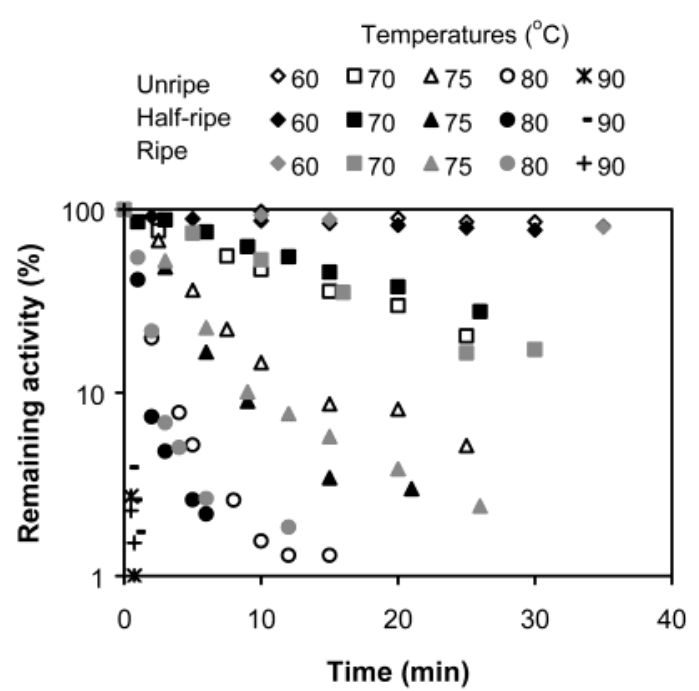

Figure 2. Heat inactivation of PPO from Kabaaşı apricots at different ripening stages.

phases, indicated that between 65 and $80{ }^{\circ} \mathrm{C}$ Kabaaşı apricots had the most thermostable PPO cresolase activity (Table 4). At low temperatures, the cresolase activity in apricots had considerably lower thermostability compared to their catecholase activity. In Kabaaşı and Çataloğlu apricots the difference between the thermostabilities of cresolase and catecholase activities reduced at higher inactivation temperatures. However, in Hacihaliloğlu apricots the considerable difference between the thermostabilities of two activities existed even at high temperatures. Thus, it is clear that the presence of TS catecholase activity (TS-PPO) in Hacıhaliloğlu apricots did not yield also a thermostable cresolase activity.

Characterization of TS-PPO. To further understand the characteristics of consistent TS-PPO, we partially purified and characterized the enzyme from ripe Hacihaliloğlu apricots (Table 5). In DEAE-cellulose column chromatography we applied two different procedures. In the first procedure we used the loosely filled column $(5 \times 2.5 \mathrm{~cm}, 10 \mathrm{~g}$ of DEAE-cellulose matrix) and collected most of the active fractions (33-41

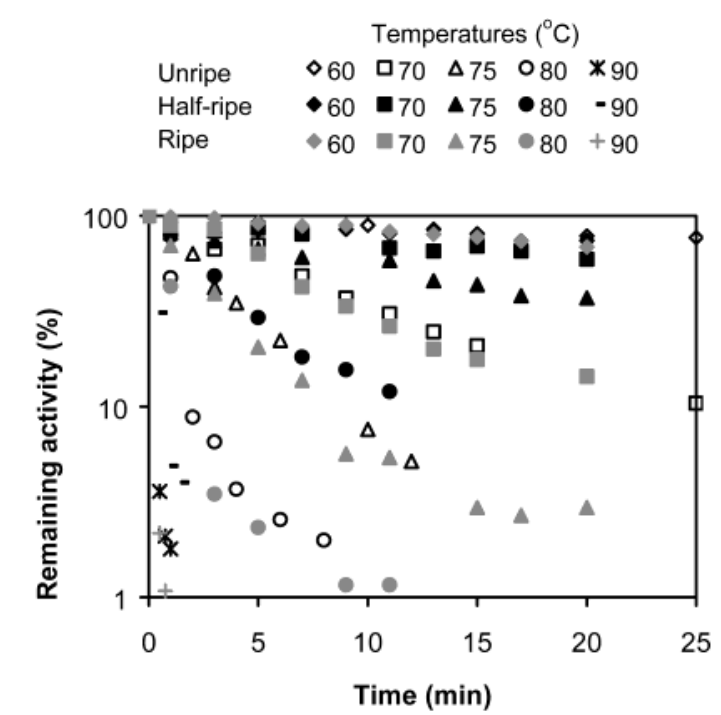

Figure 3. Heat inactivation of PPO from Çataloğlu apricots at different ripening stages.

fractions for $\mathrm{F} 1$ and 44-52 fractions for F2) of two main peaks eluted without considering the minor fractions (Figure 6A). The heat inactivation of these main fractions followed a first-order reaction kinetic. However, enzymes showed monophasic inactivation curves, and they were very heat labile (Figure 7). In fact, their $z$ values were in the range of those $z$ values obtained for TL-PPO in Kabaaşı cultivar. Although F2 was slightly more heat stable than F1, there were no considerable differences between the thermostabilities of two fractions. However, their kinetic parameters, temperature optima, and substrate specificities were quite different (Table 6). It is worth noting that the F1 oxidized both $p$-cresol and the para-diphenolic compound hydroquinone. The presence of laccase enzymes having cresolase activity was reported in the detailed review of VamosVigyazo (18). However, it is also likely that the broad substrate specificity of F1 was due to the presence of catechol oxidase isoenzymes in this fraction. The lack of monophenolase activity in F2 indicated the homogeneous character of isoenzyme forms 
Table 3. Effect of Ripening Stage and Cultivar on the Percentage of Thermostable and Thermolabile PPO Fractions in Apricots

\begin{tabular}{lcccc}
\hline & \multicolumn{3}{c}{$\%$ of fraction } \\
\cline { 3 - 4 } \multicolumn{1}{c}{ cultivar } & temp & $\begin{array}{c}\text { thermo- } \\
\text { stable }(\mathrm{TS})\end{array}$ & $\begin{array}{c}\text { thermo- } \\
\text { labile }(\mathrm{TL})\end{array}$ & $\begin{array}{c}\text { TS/TL } \\
\text { ratio }\end{array}$ \\
\hline Hacihaliloğlu & 60 & 87 & 13 & 6.7 \\
(unripe) & 70 & 83 & 17 & 4.9 \\
& 75 & 60 & 40 & 1.5 \\
& 80 & 54 & 46 & 1.2 \\
& 90 & 42 & 58 & 0.72 \\
Hacıhaliloğlu & 60 & 91 & 9 & 10.1 \\
(half-ripe) & 70 & 84 & 16 & 5.3 \\
& 75 & 84 & 16 & 5.3 \\
& 80 & 67 & 33 & 2 \\
Hacihaliloğlu & 90 & 44 & 56 & 0.79 \\
(ripe) & 60 & 83 & 17 & 4.9 \\
& 70 & 81 & 19 & 4.3 \\
& 75 & 74 & 26 & 2.8 \\
& 80 & 61 & 39 & 1.6 \\
Çataloğlu & 90 & 27 & 73 & 0.37 \\
(half-ripe) & 60 & 87 & 13 & 6.7 \\
& 70 & 90 & 10 & 9.0 \\
& 75 & 84 & 16 & 5.3 \\
& 80 & 73 & 27 & 2.7 \\
& 90 & 66 & 34 & 1.94 \\
\hline
\end{tabular}

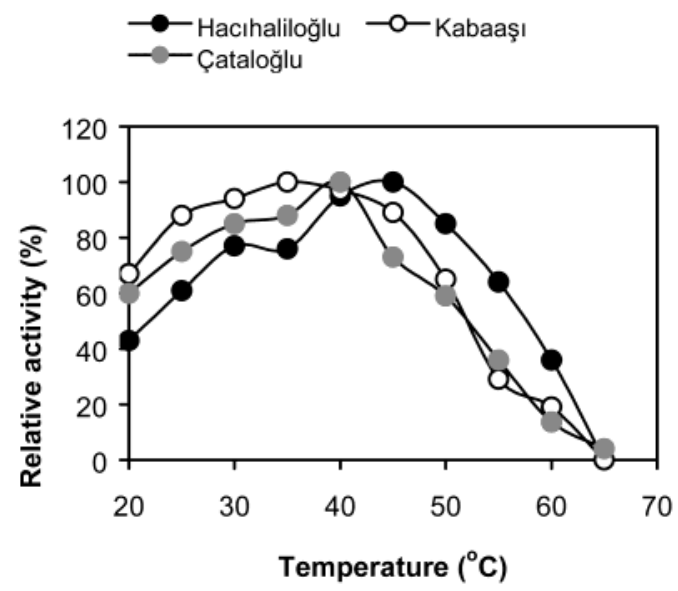

Figure 4. Effect of temperature on the activity of PPO from ripe apricots of different cultivars.

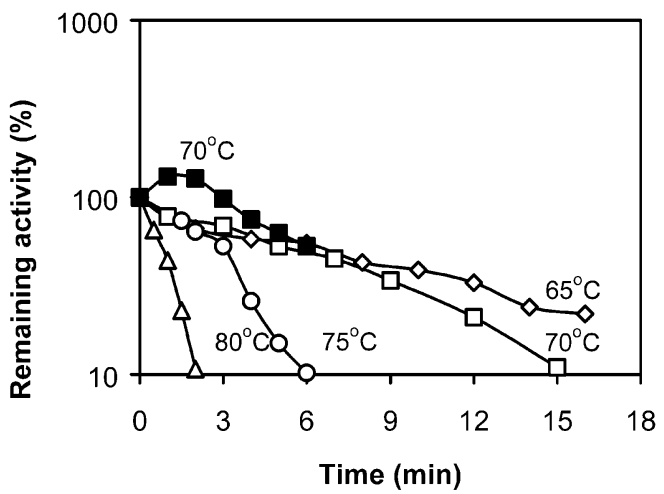

Figure 5. Heat inactivation of PPO cresolase activity from ripe Çataloğlu apricots.

found in this fraction. The labile character of PPO cresolase activity was reported by different workers $(28,29)$. Thus, its loss during purification was not surprising.

In the second procedure of partial purification, to achieve further purity we used the densely filled column $(5 \times 2.5 \mathrm{~cm}$,
Table 4. Thermostability of PPO-Cresolase Activity from Different Cultivars of Ripe Apricots

\begin{tabular}{cccl}
\hline cultivar & $\begin{array}{c}\text { temp } \\
\left({ }^{\circ} \mathrm{C}\right)\end{array}$ & $\begin{array}{c}\text { lag phase } \\
(\mathrm{min})\end{array}$ & \multicolumn{1}{c}{$D$ value $(\mathrm{min})$} \\
\hline Hacihaliloğlu & 65 & & 61.0 \\
& 70 & & 22.0 \\
& 75 & 2 & 5.0 \\
& 80 & 0.5 & 1.8 \\
& & & $z=9.6^{\circ} \mathrm{C}(0.995)^{a}$ \\
Kabaaşı & 60 & & 182.0 \\
& 65 & & 70.0 \\
& 70 & 3 & 31.0 \\
& 75 & 1 & 2.3 \\
& 80 & & $z=10.4^{\circ} \mathrm{C}(0.990)$ \\
Çataloğlu & & & 26.3 \\
& 65 & & 12.5 \\
& 70 & 9 & 4.3 \\
& 75 & 3 & \\
& 80 & 1 & \\
& & & \\
\hline
\end{tabular}

a Correlation coefficients.

$20 \mathrm{~g}$ of DEAE-cellulose matrix) and collected only the most active fractions of each peak. This time the first main fraction was sharply separated from the second fraction, which is the complex of four or five isoforms (Figure 6B). In the literature there are different reports about the number of PPO isoforms in apricots. For example, Vamos-Vigyazo (18) reported the existence of two main enzyme fractions in these fruits, whereas Chavalier et al. (30) and Fraignier et al. (31) reported the presence of a single main and several minor forms. Thus, it appears that the apricots may contain different numbers of PPO molecular forms. The temperature profiles of purified fractions determined by a 2 min incubation of enzyme extracts at different temperatures are given in Figure 8. Although some fractions $\left(\mathrm{F} 3^{\mathrm{I}}\right.$ and $\left.\mathrm{F}^{\mathrm{I}}\right)$ showed apparent activation between 50 and 60 ${ }^{\circ} \mathrm{C}$, again all of the purified enzymes showed no thermostability and were inactivated almost one decimal above $75^{\circ} \mathrm{C}$.

The results of heating studies showed that the TS-PPO enzyme lost its thermostability during the purification. In our previous studies we found that the acetone precipitation does not affect the characteristic $z$ value and biphasic inactivation curves of PPO in Hacıhaliloğlu apricots (32). Thus, although DEAE-cellulose is a weak anion exchanger and is recommended for the purification of labile proteins (33), the ion exchange processes occurring during column chromatography may cause the loss of enzyme thermostability. The results of Benjamin and Montgomery (34), who investigated the thermostability of cherry PPO, supported this hypothesis. These workers determined the half-lives of an acetone-precipitated fraction and DEAEcellulose-purified DE 1 and DE 2 fractions at $75{ }^{\circ} \mathrm{C}$ as $8,1.9$, and $2.7 \mathrm{~min}$, respectively. The reduction of the thermostability of DEAE-cellulose-immobilized enzymes is attributed to the disruption of critical internal salt bridges of enzyme (35). Thus, it seems that the thermostability of apricot PPO is due to ionic interactions.

Possible Mechanisms of TS-PPO Formation and Destabilization. Although this study shows that Hacihaliloğlu apricots contain consistent TS-PPO enzyme, there is no proof that this enzyme form is constantly present. For example, in 1995 we investigated the thermal properties of PPO from ripe Hacıhaliloğlu apricots brought from the same region, but we did not observe the TS-PPO form in these apricots. The enzyme showed its characteristic $z$ value $\left(z=12.1^{\circ} \mathrm{C}\right)$ and biphasic inactivation curves even in apricot serum, but the $D$ values of 
Table 5. Partial Purification of PPO from Ripe Hacıhaliloğlu Apricots

\begin{tabular}{|c|c|c|c|c|c|c|}
\hline purification step & $\begin{array}{c}\text { volume } \\
\text { (mL) }\end{array}$ & $\begin{array}{c}\text { total activity } \\
\text { (units) }\end{array}$ & $\begin{array}{l}\text { total protein } \\
(\mathrm{mg})\end{array}$ & $\begin{array}{l}\text { specific activity } \\
\text { (units } \mathrm{mg}^{-1} \text { ) }\end{array}$ & $\begin{array}{c}\text { yield } \\
(\%)\end{array}$ & $\begin{array}{l}\text { purity } \\
\text { (fold) }\end{array}$ \\
\hline crude extract $\left.\right|^{a}$ & 309 & 2753715 & 57.8 & 47642 & 100 & 1 \\
\hline acetone precipitation & 41 & 943582 & 7.4 & 127511 & 34 & 2.7 \\
\hline \multicolumn{7}{|c|}{ DEAE-cellulose column chromatography ${ }^{b}$} \\
\hline $\mathrm{F} 1$ & 45 & 390398 & 2.24 & 174285 & 14 & 3.7 \\
\hline $\mathrm{F} 2$ & 45 & 432878 & 1.55 & 279276 & 16 & 5.9 \\
\hline crude extract II ${ }^{a}$ & 310 & 206770 & 35.6 & 5808 & 100 & 1 \\
\hline acetone precipitation & 30 & 74520 & 4.2 & 17743 & 36 & 3.1 \\
\hline \multicolumn{7}{|c|}{ DEAE-cellulose column chromatographyc } \\
\hline$F 1^{\prime}$ & 15 & 5700 & 0.063 & 90476 & 2.8 & 15.6 \\
\hline $\mathrm{F} 2^{1}$ & 5 & 1725 & $\ll$ & & 0.8 & \\
\hline $\mathrm{F}^{\mathrm{l}}$ & 10 & 2370 & $\ll$ & & 1.1 & \\
\hline $\mathrm{F} 4{ }^{\mathrm{I}}$ & 5 & 1785 & $\ll$ & & 0.86 & \\
\hline $\mathrm{F}^{\mathrm{I}}$ & 5 & 805 & $\ll$ & & 0.39 & \\
\hline
\end{tabular}

${ }^{a}$ Crude extracts I and II were prepared by using 5 and $2 \mathrm{~g}$ of acetone powder, respectively. ${ }^{b}$ Loosely filled column. ${ }^{c}$ Tightly filled column.
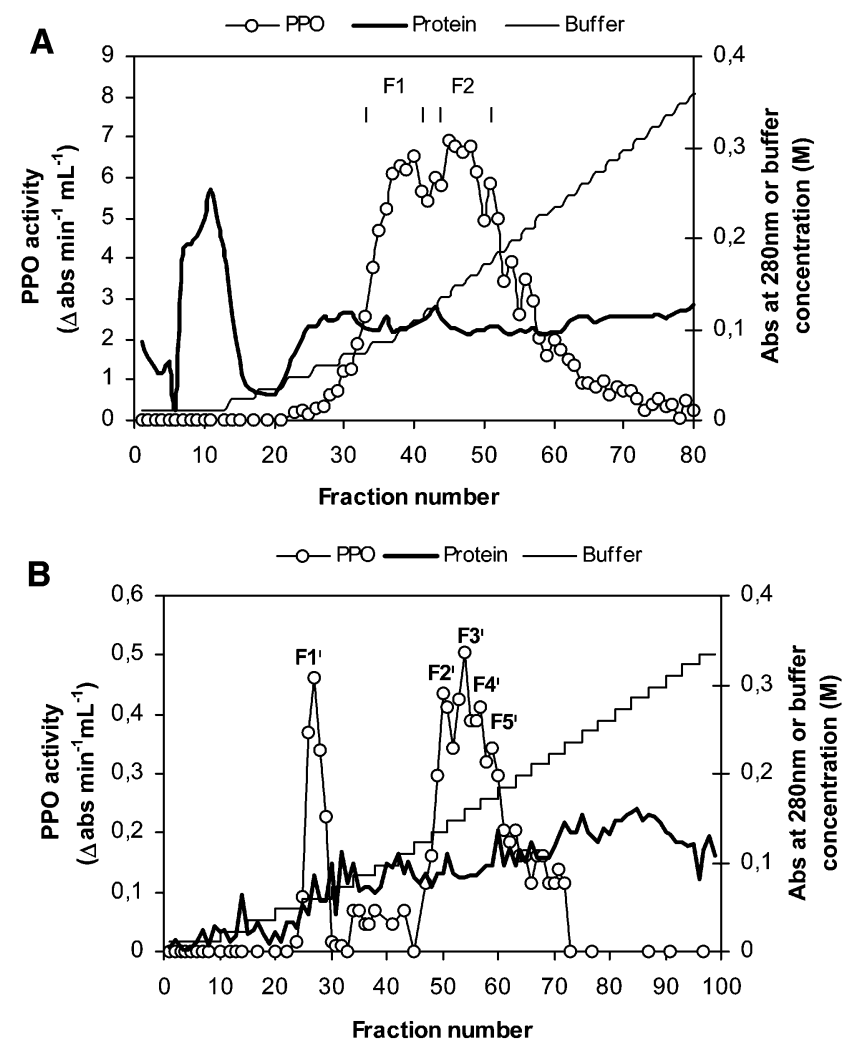

Figure 6. DEAE-cellulose chromatography of PPO from ripe Hacıhaliloğlu apricots: (A) loosely filled column $(5 \times 2.5 \mathrm{~cm}, 10 \mathrm{~g}$ of DEAE-cellulose matrix); (B) tightly filled column $(5 \times 2.5 \mathrm{~cm}, 20 \mathrm{~g}$ of DEAE-cellulose matrix).

the heat stable portion in $\mathrm{pH} 6.8$ phosphate buffer $\left(D_{55^{\circ} \mathrm{C}}=\right.$ $134.2 \mathrm{~min}$ and $D_{70^{\circ} \mathrm{C}}=21.4 \mathrm{~min}$ ) indicated the thermolabile nature of the enzyme (32). These findings suggest the importance of environmental factors in the formation of TS-PPO enzyme and the risk of selecting heat labile PPO-containing cultivars. Thus, it is important to find the in situ mechanisms related to the formation and destabilization of TS-PPO enzyme.

In the early literature it has been reported that the active forms of PPO in plants having molecular masses in the range of 40$50 \mathrm{kDa}$ derive from the in situ proteolysis of $60-70 \mathrm{kDa}$ precursors $(36-38)$. Fraignier et al. (31) reported that in apricots and in other Prunus fruits the main active PPO form is a 43 $\mathrm{kDa}$ enzyme. The possible high molecular weight precursor of this enzyme form detected with apple anti-PPO antibodies was

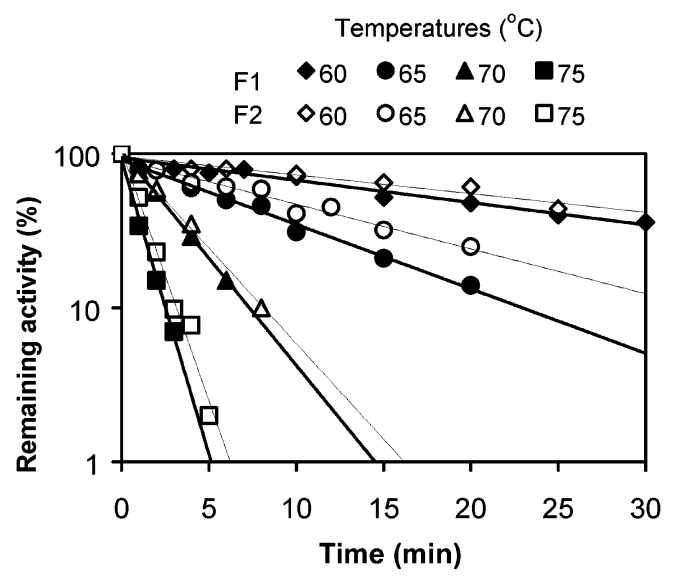

Figure 7. Heat inactivation of partially purified main PPO fractions from ripe Hacıhaliloğlu apricots.

an inactive protein of $63 \mathrm{kDa}$ molecular weight. In peaches and apricots in addition to the protease-resistant $43 \mathrm{kDa}$ major form, these researchers found also different active PPO forms having molecular weights between 27 and $40 \mathrm{kDa}$. Thus, they considered these forms to occur as a result of in vivo proteolysis of the main form by native proteases having activities that vary according to the cultivar and physiological state of fruits. Chavalier et al. (30) calculated the molecular weight of the main active PPO form in apricots, under denaturing conditions in electrophoresis, as $60 \mathrm{kDa}$ and claimed that the $43 \mathrm{kDa}$ enzyme reported by Fragnier et al. (31) should have been formed by the proteolytic cleavage of the C-terminal end of this enzyme form. The same researchers also calculated the predicted molecular weight of PPO preprotein in apricots as $67.1 \mathrm{kDa}$. The results of our partial purification studies indicate that apricots contain multiple PPO forms with different kinetic properties. This suggests the action of proteases on PPO enzyme. Thus, the possible mechanism of TS-PPO formation and destabilization may simply be explained by the action of specific proteases that cause the modification of enzyme during ripening. In the literature the presence of at least five catalytic types of proteases was reported in plant tissues (39). It was found that some proteases cause only the modification of PPO, whereas some others cause a partial digestion of the enzyme and reduce its molecular weight (40). Thus, we hypothesized that the protease profile in apricot cultivars was different. The consistent TS-PPO existed only in Hacıhaliloğlu apricots, and this may be due to the presence of specific proteases (TS-PPO-forming 
Table 6. Characteristics of Partially Purified Main PPO Fractions from Ripe Hacıhaliloğlu Apricots

\begin{tabular}{|c|c|c|}
\hline characteristic & F1 fraction & F2 fraction \\
\hline heat inactivation parameters & $\begin{array}{l}D_{60^{\circ} \mathrm{C}}=69 \mathrm{~min}, D_{65^{\circ} \mathrm{C}}=24 \mathrm{~min}, \\
D_{70^{\circ} \mathrm{C}}=7.2 \mathrm{~min}, D_{75^{\circ} \mathrm{C}}=2.6 \mathrm{~min} \\
z=10.4^{\circ} \mathrm{C}(0.990)^{\mathrm{a}}\end{array}$ & $\begin{array}{l}D_{60^{\circ} \mathrm{C}}=82 \mathrm{~min}, D_{65^{\circ} \mathrm{C}}=34 \mathrm{~min}, \\
D_{70^{\circ} \mathrm{C}}=8 \mathrm{~min}, D_{75^{\circ} \mathrm{C}}=3 \mathrm{~min} \\
z=10.1^{\circ} \mathrm{C}(0.996)\end{array}$ \\
\hline optimum pH range ${ }^{b}$ & $6.8-8$ & $6.8-7.7$ \\
\hline optimum temperature & $35^{\circ} \mathrm{C}$ & $30^{\circ} \mathrm{C}$ \\
\hline kinetic parameters & $K_{\mathrm{m}}=61 \mathrm{mM}$ & $K_{\mathrm{m}}=122.7 \mathrm{mM}$ \\
\hline & $V_{\max }=22.6 \Delta \mathrm{abs} \min ^{-1} \mathrm{~mL}^{-1}$ & $V_{\max }=36.1 \Delta$ abs $\min ^{-1} \mathrm{~mL}^{-1}$ \\
\hline & $V_{\max } / K_{m}=0.37$ & $V_{\max } / K_{m}=0.29$ \\
\hline substrate specificity & 4-methylcatechol (100) & 4-methylcatechol (100) \\
\hline & (+)-catechin (88) & (+)-catechin (35) \\
\hline & catechol (64) & catechol (45) \\
\hline & pyrogallol (50) & pyrogallol (17) \\
\hline & hydroquinone $(0.6)$ & hydroquinone $(0)$ \\
\hline & $p$-cresol (0.3) & $p$-cresol (0) \\
\hline
\end{tabular}

${ }^{a}$ Correlation coefficients. ${ }^{b}$ In the given $\mathrm{pH}$ range fractions maintain $\geq 90 \%$ of their activity.

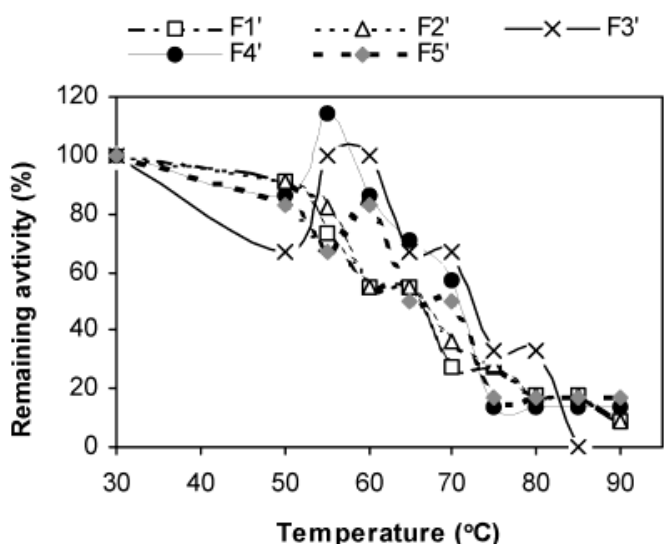

Figure 8. Temperature profiles of partially purified PPO fractions from ripe Hacıhaliloğlu apricots.

proteases) that solely determined the conformational changes necessary for TS-PPO formation. The consistency of the enzyme may be explained by the very low activity of digestive proteases (TS-PPO-destabilizing proteases) that destabilize the thermostable enzyme's conformation. The protease profile hypothesis can also be used to explain the inconsistent TS-PPO formation. This PPO form may appear when fruits contain less TS-PPOforming but more abundant destabilizing enzymes. In this case, as occurred in Çataloğlu apricots, the TS-PPO may appear very late (at the half-ripe stage) and, because of the activity of destabilizing enzymes, it cannot maintain its unique conformation for a very long time. The lack of TS-PPO, on the other hand, may occur when the TS-PPO-destabilizing enzymes prevail over the TS-PPO-forming enzymes. If these assumptions are proved, they may provide some new strategies for the solution of the TS-PPO problem by use of molecular techniques. For example, overexpression of genes related to enzyme systems responsible from the destabilization of TS-PPO may be a strategy. Also, blocking the expression of genes related to enzyme systems that catalyze TL-PPO transformation to TSPPO may be another strategy. Thus, further studies should be conducted to find the enzymes driving these mechanisms.

In addition to the specific proteases, nonproteinous substances may also contribute to the formation of TS-PPO enzyme. For example, the glycosylation may considerably increase the thermostability of a protein by affecting its hydrophilic/ hydrophobic balance and its surface charges $(41,42)$. Thus, artificial glycosylation has been used to increase the thermostability of some enzymes and proteins such as lysozyme, lipase, phosvitin, and $\beta$-lactoglobulin $(41,43-45)$.
Many enzymes, including PPO and peroxidase (POD), may naturally contain a carbohydrate conjugate (46-50). In fact, all laccases described to date are glycoproteins and they contain more carbohydrate compared to catechol oxidases $(47,51)$. Dijkstra and Walker (25) reported the presence of laccase enzyme activity in apricots. Also, in this study we determined the presence of laccase enzyme activity in one of the major fractions (F1) of PPO enzyme. Chavalier et al. (30) studied the molecular cloning and characterization of apricot PPO and reported the presence of a single putative glycosylation site in this enzyme. Thus, glycosylation may also be an important factor for the formation of TS-PPO enzyme.

Studies related to the glycosylation mechanisms of plant PPO and the roles of carbohydrate residues in the functions of these enzymes are scarce. In contrast, in their exhaustive review, Branza-Nichita et al. (52) reported that the N-glycosylation of mammalian PPO occurs in the very early stages of PPO synthesis and that the introduced carbohydrate residues contribute to the formation of the enzyme's specific conformation and to copper loading. Also, it has been reported that the nature of glycosylated carbohydrate and the degree of glycosylation may affect the affinity of proteases to their substrates $(53,54)$. Thus, in addition to different protease profiles, PPO availability may also be effective on the formation and destabilization of TS-PPO enzyme in apricots. The solution of these mechanisms may be very complicated if modifications in carbohydrates by glycosidases and glycosyltransferases are effective on the enzymes' conformation and affinity to proteases. However, the studies should first be concentrated more on the effect of specific proteases and glycosylation on PPO thermostability.

In conclusion, the results of this study showed the presence of in situ TS-PPO forming as well as destabilizing mechanisms in apricots. The loss of PPO thermostability by partial purification indicated the non-covalent nature of TS-PPO stabilization. Further studies about the molecular transformations of PPO during ripening and the roles of specific proteases and enzyme glycosylation in these transformations are needed to develop some new strategies that may be utilized by molecular techniques for a planned production of apricot cultivars provided with heat labile but normal PPO activity.

\section{ACKNOWLEDGMENT}

We thank Sedat Uslu, the general manager of Malatya Fruit Research Institute, for kindly supplying the apricots used in this study. 


\section{LITERATURE CITED}

(1) Kahn, V. Effect of proteins, protein hydrolyzates and amino acids on $o$-dihydroxyphenolase activity of polyphenol oxidase of mushroom, avocado, and banana. J. Food Sci. 1985, 50, 111115.

(2) Sapers, G. M.; Miller, R. L Browning inhibition in fresh-cut pears. J. Food Sci. 1998, 65, 342-346.

(3) Sapers, G. M.; Hicks, K. B.; Phillips, J. G.; Garzarella, L.; Pondish, D. L.; Matulaitis, R. M.; McCormack, T. J.; Sondey, S. M.; Seib, P. A.; El-Atawy, Y. S. Control of enzymatic browning in apple with ascorbic acid derivatives, polyphenol oxidase inhibitors, and complexing agents. J. Food Sci. 1989, 54, 997-1002, 1012.

(4) Santerre, C. R.; Leach, T. F.; Cash, J. N. Bisulfite alternatives in processing abrasion-peeled russet Burbank potatoes. J. Food Sci. 1991, 56, 257-259.

(5) Sapers, G. M.; Miller, R. L. Enzymatic browning control in potatoes with ascorbic acid-2-phosphates. J. Food Sci. 1992, 57, $1132-1135$.

(6) Sapers, G. M.; Miller, R. L. Heated ascorbic/citric acid solutions as browning inhibitor for pre-peeled potatoes. J. Food Sci. 1995, 60, 762-766, 776.

(7) Gunes, G.; Lee, C. Y. Color of minimally processed potatoes as affected by modified atmosphere packaging and antibrowning agents. J. Food Sci. 1997, 62, 572-575, 582.

(8) Bachem, C. W. B.; Speckmann, G. J.; Van der Linde, P. C. G.; Verheggen, F. T. M.; Hunt, M. D.; Steffens, J. C.; Zabeau, M. Antisense expression of polyphenol oxidase genes inhibits enzymatic browning in potato tubers. Bio/Technology 1994, 12, 1101-1105.

(9) Coetzer, C.; Corsini, D.; Love, S.; Pavek, J.; Tumer, N. Control of enzymatic browning in potato (Solanum tuberosum L.) by sense and antisense RNA from tomato polyphenol oxidase. $J$. Agric. Food Chem. 2001, 49, 652-657.

(10) Li, L.; Steffens, J. C. Overexpression of polyphenol oxidase in transgenic plants results in enhanced bacterial disease resistance. Planta 2002, 215, 239-247.

(11) Thomas-Berberan, F. A.; Espin, J. C. Phenolic compounds and related enzymes as determinants of quality in fruits and vegetables. J. Sci. Food Agric. 2001, 81, 853-876.

(12) Gomes, M. R. A.; Ledward, D. A. Effect of high-pressure treatment on the activity of some polyphenol oxidases. Food Chem. 1996, 56, 1-5.

(13) Seyderhelm, I.; Boguslawski, S.; Michaelis, G.; Knorr, D. Pressure induced inactivation of selected food enzymes. J. Food Sci. 1996, 61, 308-310.

(14) de Daza, M. S. T.; Alzamora, S. M.; Welti-Chanes, J. Minimally processed high moisture fruit products by combined methods: Result of a multinational project. In Food Engineering; Fito, P., Ortega-Rodriguez, E., Barbosa-Canovas, G. V., Eds.; Chapman and Hall, ITP: New York, 1997; pp 161-180.

(15) Valle, J. M.; Aranguiz, V.; Leon, H. Effects of blanching and calcium infiltration on PPO activity, texture, microstructure and kinetics of osmotic dehydration of apple tissue. Food Res. Int. 1998, 31, 557-569.

(16) Devece, C.; Rodriguez-Lopez, J. N.; Fenoll, L. G.; Tudela, J.; Catala, J. M.; Reyes, E.; Garcia-Canovas, F. Enzyme inactivation analysis for industrial blanching applications: Comparison of microwave, conventional, and combination heat treatments on mushroom polyphenoloxidase activity. J. Agric. Food Chem. 1999, 47, 4506-4511.

(17) Lacroix, M.; Ouattara, B. Combined industrial processes with irradiation to assure innocuity and preservation of food productsa review. Food Res. Int. 2000, 33, 719-724.

(18) Vamos-Vigyazo, L. Polyphenol oxidase and peroxidase in fruits and vegetables. CRC Crit. Rev. Food Sci. Nutr. 1981, 15, 49127.

(19) Ponting, J. D.; Bean, R. S.; Notter, G. K.; Makower, B. Degree of heat-inactivation of polyphenol oxidase and quality of frozen apricot puree. Food Technol. 1954, 8, 573-575.
(20) Leonard, S.; Marsh, G. L.; York, G. K.; Heil, J. R.; Wolcott, T.; Coggins, S. Determination of flame sterilisation process for apricot halves in $303 \times 406$ cans. J. Food Sci. 1976, 41, 12221224.

(21) Arslan, O.; Temur, A.; Tozlu, İ. Polyphenol oxidase from Malatya apricot (Prunus armeniaca L.). J. Agric. Food Chem. 1998, 46, 1239-1241.

(22) Yemenicioğlu, A.; Cemeroğlu, B. Hale Haven şeftalilerinde polifenol oksidaz enzimlerinin bazı nitelikleri. Tr. J. Agric. For. 1998, 22, 261-265.

(23) Cemeroğlu, B. Meyve ve sebze işleme endüstrisinde temel analiz metodları. Biltav Yayınları 02-2: Ankara, Turkey, 1992; pp 239-264.

(24) Yemenicioğlu, A.; Özkan, M.; Cemeroğlu, B. Heat inactivation kinetics of apple polyphenoloxidase and activation its latent form. J. Food Sci. 1997, 62, 508-510.

(25) Dijkstra, L.; Walker, J. R. L. Enzymic browning in apricots (Prunus armeniaca). J. Sci. Food Agric. 1991, 54, 229-234.

(26) Harris, D. A. Spectrophotometric assays. In Spectrophotometry and Spectrofluorometry; Harris, D. A., Bashford, C. L., Eds.; IRL Press: Oxford, U.K., 1987; pp 59-60.

(27) Yamamoto, H. S.; Steinberg, M. P.; Nelson, A. I. Kinetic studies on the heat inactivation of peroxidase in sweet corn. J. Food Sci. 1962, 27, 113-118.

(28) Sanchez-Ferrer, A.; Laveda, F.; Garcia-Carmona, F. Cresolase activity of potato tuber partially purified in a two-phase partition system. J. Agric. Food Chem. 1993, 41, 1225-1228.

(29) Espin, J. C.; Morales, M.; Varon, R.; Tudela, J.; Garcia-Canovas, F. Monophenolase activity of polyphenol oxidase from verdedoncella apple. J. Agric. Food Chem. 1995, 43, 28072812.

(30) Chavalier, T.; Rigal, D.; Mbeguie-A-Mbeguie, D.; Gauillard, F.; Richard-Forget, F.; Fils-Lycaon, B. R. Molecular cloning and characterisation of apricot fruit polyphenol oxidase. Plant Physiol. 1999, 119, 1261-1269.

(31) Fragnier, M.; Marques, L.; Fleuriet, A.; Macheix, J. Biochemical and immunochemical characterisation of polyphenol oxidase from different prunus fruits. J. Agric. Food Chem. 1995, 43, 2375-2380.

(32) Yemenicioğlu, A. Time-temperature relationships for thermal inactivation of polyphenol oxidase in apricot. Masters Thesis, Ankara University Graduate School of Natural and Applied Sciences, Department of Food Engineering, 1996.

(33) Roe, S. Separation based on structure. In Protein Purification Methods; Harris, E. L. V., Angal, S., Ed.; IRL Press: Oxford, U.K., 1989; pp 202-216.

(34) Benjamin, N. D.; Montgomery, M. W. Polyphenol oxidase of Royal Ann cherries: Purification and characterisation. J. Food Sci. 1973, 38, 799-806.

(35) Wasserman, B. P. Thermostable enzyme production. Food Technol. 1984, 38, 78-89, 98.

(36) Hind, G.; Marshak, D. R.; Coughan, S. J. Spinach polyphenol oxidase: Cloning, characterization, and relation to a putative protein kinase. Biochemistry 1995, 34, 8157-8164.

(37) Espin, J. C.; Van Leeuwen, J.; Wichers, H. J. Kinetic study of the activation process of a latent mushroom (Agaricus bisporus) tyrosinase by serine proteases. J. Agric. Food Chem. 1999, 47, 3509-3517.

(38) Mazzafera, P.; Robinson, S. P. Characterisation of polyphenol oxidase in coffee. Phytochemistry 2000, 55, 285-296.

(39) Priolo, N.; del Valle, S. M.; Arribere, M. C.; Lopez, L.; Caffini, $\mathrm{N}$. Isolation and characterisation of a cysteine protease from the latex of Araujia hortorum fruits. J. Protein Chem. 2000, 19, 3949.

(40) King, R. S.; Flurkey, W. H. Effect of limited proteolysis on broad bean polyphenol oxidase. J. Sci. Food Agric. 1987, 41, 231240.

(41) Kitabatake, N.; Cuq, J. L.; Cheftel, J. C. Covalent binding of glycosyl residues to $\beta$-lactoglobulin: Effects on solubility and heat stability. J. Agric. Food Chem. 1985, 33, 125-130. 
(42) Lango, M. L.; Combes, D. Thermostability of modified enzymes: a detailed study. J. Chem. Technol. Biotechnol. 1999, 74, 2532.

(43) Nakamura, S.; Kato, A.; Kobayashi, K. Bifunctional lysozymegalactomannan conjugate having excellent emulsifying properties and bactericidal effect. J. Agric. Food Chem. 1992, 40, 735739.

(44) Shu, Y.; Sahara, S.; Nakamura, S.; Kato, A. Effects of the length of polysaccharide chains on the functional properties of the Maillard-type lysozyme-polysaccharide conjugate. J. Agric. Food Chem. 1996, 44, 2544-2548.

(45) Casa, R. M.; Guisan, J. M.; Sanchez-Montero, J. M.; Sinisterra, J. V. Modification of the activities of two different lipase from Candida rugosa with dextrans. Enzyme Microb. Technol. 2002, 30, 30-40.

(46) Floris, G.; Medda, R.; Rinaldi, A. Peroxidase from Ipomoea batatas seedlings: Purification and properties. Phytochemistry 1984, 23, 1527-1529.

(47) Mayer, A. M. Polyphenol oxidases in plants-recent progress. Phytochemistry 1987, 26, 11-20.

(48) Lee, M. Y.; Kim, S. S. Characteristics of six isoperoxidases from Korean radish root. Phytochemistry 1994, 35, 287-290.

(49) Fujita, S.; bin Saari, N.; Maegawa, M.; Tetsuka, T.; Hayashi, N.; Tono, T. Purification and properties of polyphenol oxidase from cabbage (Brassica oleracea L.). J. Agric. Food Chem. 1995 , $43,1138-1142$.

(50) Wolf, S. M.; Ferrari, R. P.; Traversa, S.; Biemann, K. Determination of the carbohydrate composition and disulfide bond linkages of bovine lactoperoxidse by mass spectrometri. J. Mass Spectrom. 2000, 35, 210-217.

(51) Mayer, A. M.; Staples, R. C. Laccase: new functions for an old enzyme. Phytochemistry 2002, 60, 551-565.

(52) Branza-Nichita, N.; Petrescu, A. J.; Negroiu, G.; Dwek, R. A.; Petrescu, S. M. N-Glycosylation processing and glycoprotein folding-lessons from the tyrosinase-related proteins. Chem. Rev. 2000, 100, 4697-4711.

(53) Caer, D.; Colas, B. Protease susceptibility and amino group accessibility to trinitrobenzenesulfonic acid of legumin during its glycosylation. J. Agric. Food Chem. 1993, 41, 544-546.

(54) Horton, H. R.; Moran, L. A.; Ochs, R.; Rawn, J. D.; Scrimgeour, K. G. Principles of Biochemistry; Prentice Hall: London, U.K., 1996; pp 238-240.

Received for review September 26, 2002. Revised manuscript received December 12, 2002. Accepted January 2, 2003.

JF025988Q 